\title{
Pengaruh Konsentrasi Kepemilikan, dan Keterbukaan, Diversifikasi, Terhadap Risiko Bank
}

\author{
Risal Rinofah ${ }^{1}$ \\ Prathama Nugraha ${ }^{2}$ \\ ${ }^{1}$ Fakultas Ekonomi UST Yogyakarta \\ ${ }^{2}$ Magister Sains Fakultas Ekonomika dan Bisnis UGM
}

\begin{abstract}
Bank is a financial institution that must able to guarantee the funds entrusted by the community. This guarantee related to the ability of banks to maintain their risk levels. As revealed by the theories and previous studies, a bank level of risk taking might determined by the concentration of the ownership, a party that determines the bank management. Additionally compliance in carrying out the principles of openness and the ability of banks to obtain other revenues outside the main business as intermediaries of funds from customers to the creditors also shown to determine the level of bank risk taking.

By using multiple regression analysis techniques and observation of data during a period of 5 years, this study found that the level of a bank's risk taking is influenced by the disclosure of information and income diversification. The higher the index the information disclosure and diversification the lower the risk. Ownership concentration has shown the right coefficient direction corresponding to the risk but it is not statistically significant
\end{abstract}

Key Words: Risk Taking, Ownership Concentrations, Information Disclosure, Bank Income

\section{PENDAHULUAN}

Saat ini kedudukan Bank dalam masyarakat dan perekonomian sangat vital. Bank dapat dianalogikan sebagai urat nadi bagi perekonomian dan merupakan badan usaha yang mengkaitkan berbagai pihak sehingga perbankan menjadi industri yang perlu diamati perkembangan kinerjanya. Kinerja bank sangat tergantung dari kemampuan manajemen dalam mengelola bank. Jika manajemen mampu membuat bank berkinerja baik, maka ada insentif yang bisa mereka dapatkan. Namun satu pihak lagi yang tak kalah penting dalam mempengaruhi kinerja suatu perusahaan adalah para pemilik. Pemilik adalah pihak yang dapat mengendalikan para manajemen melalui perantaraan para komisaris yang menjadi wakil mereka. Kepemilikan suatu bank bisa lebih dari satu orang sehingga strukturnya untuk setiap bank juga dapat berbeda serta berdampak pada konsentrasi kepemilikan. Setelah kasus likuidasi besar-besaran pada krisis 1997 otoritas keuangan dunia seperti IMF dan Bank Dunia langsung menyerukan perlunya transparansi dan bank menjadikan pendisiplinan pasar ini sebagai pelengkap alat pengawasan dan regulasi. Keterbukaan menjadikan publik dapat memonitor bank bersangkutan dan dalam kondisi seperti ini para manajer akan bertindak dan mengambil kebijakan dengan hati-hati.

Tingkat persaingan yang ketat membuat bank harus kreatif dalam memperoleh sumber-sumber pemasukan lain di luar pemasukan dari bunga (fee based income). Meskipun fee based terlihat menguntungkan namun tidak berarti bank terbebas dari risiko dari upaya diversifikasi ini. Bertambahnya produk jasa bank ini akan merubah profil risiko suatu bank. Di Indonesia, tidak banyak yang meneliti keterkaitan ketiga variabel tersebut dengan risiko (risk taking). Oleh karena itu, penulis berharap penelitian ini nantinya dapat menambah dan melengkapi 
pustaka untuk studi-studi selanjutnya yang berkaitan dengan topik tersebut.

\section{Rumusan Masalah}

Dari penjelasan di atas maka permasalahan yang ingin dijawab oleh penelitian adalah: apakah konsentrasi kepemilikan, diversifikasi dan keterbukaan berpengaruh terhadap risiko (risk-taking) bank

\section{Tujuan Penelitian}

Penelitian ini bertujuan menguji pengaruh konsentrasi kepemilikan, diversifikasi dan keterbukaan terhadap risiko (risk-taking) bank di Indonesia.

\section{Manfaat Penelitian}

Penelitian ini diharapkan dapat memberikan dukungan bagi penelitianpenelitan terdahulu sekaligus menjadi tambahan referensi baru untuk penelitian dengan topik yang serupa serta diharapkan dapat memberi masukan baik bagi bank maupun otoritas regulator perbankan dalam pembuatan kebijakan.

\section{TINJAUAN PUSTAKA DAN PENGEMBANGAN HIPOTESIS Bank}

Menurut Weston dan Copeland (1995) bank merupakan lembaga intermediasi atau sering dikenal dengan sebutan financial intermediaries, yang berperan sangat strategis sebagai akselelator kegiatan ekonomi melalui penghimpunan dana dari kelompok masyarakat surplus atau surplus spending units, selanjutnya dana tersebut dikelola dan disalurkan sebagai fasilitas perkreditan ke berbagai kelompok masyarakat yang membutuhkan atau deficit spending units dalam berbagai sektor perekonomian. Sedangkan menurut Undang-undang Nomor 10 Tahun 1998 bank adalah Badan usaha yang menghimpun dana dari masyarakat dalam bentuk simpanan, dan menyalurkannya kepada masyarakat dalam bentuk kredit dan/atau bentuk-bentuk lainnya dalam rangka meningkatkan taraf hidup masyarakat banyak. Menurut data Bank Indonesia mengenai institusi perbankan di Indonesia pada Mei 2010 setidaknya terdapat 1983 bank. Menurut
Kasmir (2008) jenis Bank berdasarkan fungsinya adalah: 1) Bank Sentral, merupakan lembaga negara yang mempunyai wewenang untuk mengeluarkan alat pembayaran yang sah dari suatu negara, merumuskan dan melaksanakan kebijakan moneter, mengatur dan menjaga kelancaran sistem pembayaran, mengatur dan mengawasi perbankan serta menjalan fungsi sebagai lender of the last resort dan bertujuan mencapai dan memelihara kestabilan nilai rupiah melalui kebijakan moneter secara berkelanjutan, konsisten, transparan, dan harus mempertimbangkan kebijakan umum pemerintah di bidang perekonomian. 2) Bank Umum, yang melaksanakan kegiatan usaha secara konvensional dan atau berdasarkan prinsip syariah yang dalam kegiatannya memberikan jasa dalam lalu lintas pembayaran. 3) Bank Perkreditan Rakyat (BPR), melaksanakan kegiatan usaha secara konvensional atau berdasarkan prinsip syariah yang dalam kegiatannya tidak memberikan jasa dalam lalu lintas pembayaran. Sedangkan jenis bank berdasarkan Kepemilikan: 1) Bank Milik Pemerintah, Bank yang baik akta pendirian maupun modalnya dimiliki oleh pemerintah, sehingga seluruh keuntungan bank dimiliki oleh pemerintah pula. Selain itu ada juga bank milik pemerintah daerah yang terdapat di daerah tingkat I dan tingkat II masing-masing provinsi. 2). Bank Milik Swasta Nasional, adalah bank yang seluruh atau sebagian besar modalnya dimiliki oleh swasta nasional serta akta pendiriannya pun didirikan oleh swasta. 3) Bank Milik Asing, bank jenis ini merupakan cabang dari bank yang ada di luar negeri, baik milik swasta asing atau pemerintah asing. Sedangkan jenis bank berdasarkan kegiatan operasionalnya: 1) Bank Konvensional, adalah bank yang dalam operasionalnya menerapkan metode bunga, karena metode bunga sudah ada terlebih dahulu, menjadi kebiasaan dan telah dipakai secara meluas dibandingkan dengan metode bagi hasil. Bank konvensional pada umumnya beroperasi dengan mengeluarkan produkproduk untuk menyerap dana masyarakat antara lain tabungan, simpanan deposito, simpanan giro; menyalurkan dana yang telah 
dihimpun dengan cara mengeluarkan kredit antara lain kredit investasi, kredit modal kerja, kredit konsumtif, kredit jangka pendek; dan pelayanan jasa keuangan antara lain kliring, inkaso, kiriman uang, Letter of Credit, dan jasa-jasa lainnya. 2) Bank Syariah, adalah bank yang beroperasi sesuai dengan prinsip-prinsip syariah Islam. Falsafah dasar beroperasinya bank syariah yang menjiwai seluruh hubungan transaksinya adalah efesiensi, keadilan, dan kebersamaan.

\section{Konsentrasi Kepemilikan (Ownership Concentration) \\ Struktur kepemilikan saham} menunjukkan bagaimana distribusi kekuasaan dan pengaruh pemegang saham atas kegiatan operasional perusahaan. Dalam sebuah badan usaha sebaran kepemilikan dapat dikategorikan dalam dua macam, yaitu (a) kepemilikan menyebar (dispersed ownwership) dan kepemilikan terkonsentrasi (closely held/concentrated). Kepemilikan saham terkonsentrasi adalah keadaan dimana sebagian besar saham dimiliki oleh sebagian kecil individu atau kelompok, sehingga pemegang saham tersebut memiliki jumlah saham yang relatif dominan. Berdasarkan hasil penelitiannya, La Porta dkk. (1998) menemukan bahwa French origin countries group (termasuk Indonesia) memiliki konsentrasi kepemilikan tertinggi dibandingkan dengan tiga origin countries group yang lain. Mereka juga berpendapat bahwa lemahnya perlindungan hukum dan lingkungan institusional (law and enforcement) berkaitan sangat erat dengan kepemilikan yang terkonsentrasi (La Porta dkk., 1998). Sedangkan kepemilikan menyebar adalah jika kepemilikan saham secara relatif merata ke publik. Konsentrasi kepemilikan dapat menjadi mekanisme internal pendisiplinan manajemen karena dengan kepemilikan yang besar menjadikan pemegang saham memiliki akses informasi yang signifikan untuk mengimbangi keuntungan informasional yang dimiliki manajemen. Kepemilikan juga dapat identifikasikan berdasarkan pihak yang memilikinya: 1) kepemilikan manajerial yang merupakan kepemilikan saham oleh manajemen perusahaan yang diukur dengan persentase jumlah saham yang dimiliki oleh manajemen (Mehran et al., (1992). 2) Kepemilikan institusional yang merupakan kepemilikan saham oleh pemerintah, institusi keuangan, institusi berbadan hukum, institusi luar negeri, dana perwalian serta institusi lainnya.

\section{Keterbukaan (Disclosure)}

Disclosure adalah istilah yang dikatakan sebagai keterbukaan (transparansi) informasi oleh perusahaan. Menurut undangundang Pasar Modal No.8/1995 pasal 1 angka 25 prinsip keterbukaan mengharuskan setiap perusahaan publik atau emiten untuk menginformasikan kepada masyarakat seluruh informasi materiil dalam waktu yang tepat mengenai usahanya atau efeknya yang dapat berpengaruh terhadap keputusan pemodal terhadap efek dimaksud dan atau harga dari efek tersebut (Sandria, 2000). Keterbukaan yang dimaksud adalah pengungkapan data perusahaan secara lengkap dan menyeluruh menyangkut data keuangan, pengurus dan sebagainya dengan tujuan agar diketahui secara luas oleh masyarakat umum. Emiten emiten dilarang memberikan infornasi yang salah, informasi yang setengah benar, atau memberikan informasi yang tidak lengkap terhadap fakta/informasi material. Apabila emiten tidak memberikan informasi yang benar maka hal tersebut dapat menimbuikan salah pengertian (misleading) bagi investor dalam memberikan penilaian. Informasi tersebut dibedakan menjadi dua, yaitu informasi keuangan dan informasi nonkeuangan. Berdasarkan Keputusan Ketua Bapepam No. Kep-80/PM/1996 Peraturan No.X.K.2 tentang Kewajiban Penyampaian Laporan Keuangan Berkala laporan keuangan yang wajib disampaikan oleh Emiten terdiri dari laporan keuangan tahunan dan laporan keuangan tengah tahunan yang terdiri (Fuady, 1993): Neraca, Laporan laba rugi, Laporan saldo laba, Laporan arus kas, Catalan atas laporan keuangan, serta Laporan Iain dan penjelasan yang merupakan bagian integral dari laporan keuangan jika dipersyaratkan, seperti laporan komitmen dan kontinjensi 
untuk Emiten dan Perusahaan Publik yang bergerak dalam bidang perbankan.

\section{Diversifikasi}

Diversifikasi yang dimaksud disini adalah diversifikasi pendapatan bank. Komponen utama pendapatan bank adalah bunga (interest income) dan yang kedua adalah pendapatan yang di dapat oleh bank dari jasa perbankan (fee based). Cakupan usaha yang menghasilkan fee based antara lain: Pendapatan Provisi \& Komisi , Pendapatan Transaksi Devisa, dan Pendapatan Lainnya. Bank sebagai perantara keuangan selalu dihadapkan pada situasi dilematis, antara lain : risiko besar-pendapatan besar atau high risk-high return yang berupa kredit macet yang setiap saat dapat terjadi dalam dunia perbankan. Sejak adanya kebijakan tentang tigh money policy pada tahun 1990, bank tidak lagi hanya mengandalkan sumber pendapatan dari hasil bunga saja melainkan mulai beralih untuk meningkatkan pendapatannya dari jasa-jasa pelayanan yang diberikan bank yaitu Fee-based Income. Sinungan (1994) menyatakan bahwa pendapatan yang berasal dari fee-based merupakan sumber pendapatan yang paling diperhitungkan dalam bisnis perbankan dewasa ini. Seperti halnya pada investasi yang dilakukan oleh individu, diversifikasi bermanfaat untuk mengurangi profil risiko bank (Smith et.al, 2003). Sehingga jika pendapatan dari operasional utama (bunga) tidak mencukupi untuk menutupi biaya operasional bank, maka pendapatanpendapatan di luar usaha inti ini dapat digunakan untuk menutupinya.

\section{Risiko Bank (Bank Risk Taking)}

Peristiwa penutupan bank yang telah beberapa kali terjadi di Indonesia memberikan petunjuk bahwa tidak semua bank memiliki manajemen yang baik dan didukung oleh pemilik yang mengerti betul mengenai bisnis bank itu sendiri. Penutupan bank-bank tersebut bisa menjadi bukti rendahnya kemampuan manajemen bank untuk mengantisipasi besarnya risiko-risiko yang dihadapi oleh bank tersebut sehingga bankbank tersebut bergerak menuju kehancuran.
Berdasarkan kebijakan Bank Indonesia mengenai sistem pengawasan bank, risikorisiko bank $^{1}$ antara lain: 1) Risiko Kredit (Risiko yang timbul sebagai akibat kegagalan counterparty memenuhi kewajibannya. 2) Risiko Pasar (Risiko yang timbul karena adanya pergerakan variabel pasar dari portofolio yang dimiliki oleh Bank yang merugikan Bank). 3) Risiko Likuiditas (Risiko yang antara lain disebabkan Bank tidak mampu memenuhi kewajiban yang telah jatuh waktu. 4) Risiko Operasional (Risiko yang antara lain disebabkan adanya ketidakcukupan dan atau tidak berfungsinya proses internal, kesalahan manusia, kegagalan sistem, atau adanya problem eksternal yang mempengaruhi operasional Bank. Semua jenis risiko tersebut berpotensi mengantar bank ke dalam kebangkrutan. Sebagai contoh jika kredit (risiko kredit) yang di salurkan bank pada masyarakat mengalami kemacetan, apalagi dalam jumlah yang besar maka bank dapat menghadapi kesulitan membiayai operasionalnya.

\section{Capital Adequacy Ratio (CAR) dan Non Performing Loan (NPL) \\ Capital Adequacy Ratio (CAR) atau} sering disebut rasio permodalan merupakan modal dasar yang harus dipenuhi oleh bank. Menurut Susilo (2000), kecukupan modal merupakan faktor yang sangat penting bagi bank dalam rangka pengembangan usaha dan menampung risiko kerugian. Jika nilai CAR tinggi maka bank tersebut mampu membiayai kegiatan operasional dan memberikan kontribusi yang cukup besar bagi profitabilitas. Bank Indonesia menetapkan batas CAR minimum adalah sebesar $8 \%$. Sedangkan Mudrajad Kuncoro dan Suhardjo (2002:562) mendefinisikan kecukupan modal (capital adequacy) sebagai kemampuan bank dalam mempertahankan modal yang mencukupi dan kemampuan manajemen bank dalam mengidentifikasi, mengukur,

1

http://www.bi.go.id/web/id/Perbankan/Ikhtisar+Perban kan/Pengaturan+dan+Pengawasan+Bank/Sistem+Peng awasan+Bank/ 
mengawasi dan mengontrol risiko-risiko yang timbul yang dapat berpengaruh terhadap besarnya modal bank.

NPL atau risiko kredit merupakan risiko yang terkait dengan kemungkinan kegagalan klien dalam memenuhi kewajiban membayarnya atau tidak dapat melunasi hutangnya (Imam Gozali, 2007). Risiko kredit dapat timbul karena beberapa hal, antara lain: Adanya kemungkinan pinjaman yang diberikan oleh bank atau obligasi (surat hutang) yang dibeli oleh bank tidak terbayar atau hal lainnya. Dalam memberikan kredit, bank harus terlebih dahulu melakukan analisis terhadap kemampuan debitur untuk memenuhi kewajibannya. Selanjutnya bank harus melakukan pemantauan terhadap penggunaan kredit dan kepatuhan debitur dalam memenuhi kewajibannya. Tindakantindakan demikian berguna untuk memperkecil risiko tidak tertagihnya kredit.

\section{Penelitian Terdahulu dan Pengembangan Hipotesis}

Tingkat konsentrasi kepemilikan pada suatu bank diyakini memiliki dampak terhadap risiko bank yang bersangkutan. Paligorova (2009) menemukan bahwa perusahaan yang kepemilikannya lebih menyebar memberikan kinerja yang lebih baik daripada perusahaan yang kepemilikannya lebih terkonsentrasi karena kepemilikan yang tersebar menjadikan adanya keseimbangan kepentingan diantara para pemilik dan tersebarnya pihak pengendali kebijakan perusahaan. Selain itu konsentrasi kepemilikan juga dapat mempengaruhi risiko (risk taking) sebuah perusahaan. Wright et.al (1996) mengatakan shareholder dengan kepemilikan besar dapat mempengaruhi karakter sebuah perusahaan dalam menerima risiko. Kepemilikan dalam jumlah besar (dominan) oleh seseorang atau kelompok cenderung menginginkan kebijakan investasi yang konservatif mengingat besarnya risiko yang mungkin mereka terima akibat kepemilikan mereka yang besar itu (Paligorova, 2009). Beberapa penelitian sebelumnya antara lain: Chun et, al (2010) Laeven dan Levine (2006), Cebenoyan et.al (1999), Demsetz dan Lehn (1985),
Himmelberg et,al (1999), serta Holderness, et,al (1999) menemukan bahwa konsentrasi kepemilikan berdampak positif pada risk taking. Artinya, semakin terkonsentrasi kepemilikan di sebuah bank maka semakin tinggi risk taking-nya. Hal ini disebabkan karena faktor monitoring yang lemah disebabkan para pemilik terkonsentrasi pada satu kelompok saja (Kim et al, 2007).

\section{H1: Konsentrasi kepemilikan berpengaruh positif terhadap risiko bank}

Pendisiplinan pasar (pengungkapan informasi) adalah gagasan bahwa tindakan pemegang saham, kreditur, dan pihak yang bersangkutan dengan perusahaan perbankan dapat mempengaruhi investasi, operasional, dan risiko pengambilan keputusan manajer bank (Flannery 2001, Bliss dan Flannery 2002). Pelaku pasar harus dapat mengakses informasi berkaitan prospek perusahaan baik kondisi terkini maupun di masa depan untuk mengukur prospek perusahaan baik di masa kini maupun masa mendatang. Misalnya informasi tentang jumlah kredit yang mereka salurkan dan termasuk kredit-kredit yang bermasalah (Hirtle, 2007). Adanya tindakan monitoring seperti ini membuat para manajer akan bertindak dan mengambil kebijakan dengan hati-hati untuk menghindari respon negatif dari publik. Dengan demikian terlihat bahwa keterbukaan secara langsung dapat mempengaruhi bank dalam pengambilan risiko (risk taking). Cordella dan Yeyati (1998) menyimpulkan bahwa semakin tinggi portfolio risiko investasi perusahaan maka semakin tinggi pula kemungkinan mengalami kebangkrutan karena tingginya pinalti yang bisa diberikan oleh para penyandang dana akibat portfolio risiko perusahaan yang tinggi tersebut. Boro (1986) menyatakan bahwa keterbukaan akan memperkecil kebiasaan manajer perusahaan dalam mengambil kebijakan-kebijakan yang bersifat spekulatif dan berisiko tinggi. Bauman dan Nier (2004) melakukan penelitian dengan sampel 729 bank di 32 negara menemukan bahwa tingkat risiko pada modal bank dipengaruhi oleh adanya disiplin pasar (keterbukaan). Laeven dan Levine (2006) menemukan bahwa semakin baik corporate governance (keterbukaan) sebuah bank maka semakin 
rendah pula keinginan manajer untuk mengambil kebijakan-kebijakan yang dapat mempertinggi profil risiko perusahaan. Selanjutnya, penelitian oleh Ciancanelli dan Gonzales (2000) menyimpulkan bahwa semakin ketat corporate governance (keterbukaan) di suatu negara maka semakin baik pula kepatuhan perusahaan dalam memilih kebijakan-kebijakan yang memiliki risiko rendah atau dengan kata lain risiko suatu bank semakin rendah.

\section{H2: Keterbukaan berpengaruh negatif terhadap risiko bank}

Dalam tingkat persaingan yang ketat bank harus kreatif dalam memperoleh sumber-sumber pemasukan lain di luar pemasukan dari bunga seperti: adalah pendapatan dari hasil transaksi valuta asing, provisi, fee dan pendapatan operasional lainnya. Pendapatan-pendapatan di luar bunga ini sering disebut dengan istilah fee based income. Diversifikasi ini merupakan upaya agar bank tidak tergantung pada pendapatan dari sektor perkreditan dan mempertahankan tingkat pendapatan yang memadai. Meskipun fee based terlihat menguntungkan namun tidak berarti bank terbebas dari karena bertambahnya produk jasa bank ini akan merubah profil risiko suatu bank. Tacneng (2009) melakukan penelitian di Philipina menyimpulkan bahwa diversifikasi produk jasa bank memiliki dampak terhadap risiko bank (risk taking). Penelitian oleh (Smith et.al, 2003) menyimpulkan bahwa fee based mampu menurunkan risiko dari suatu bank karena semakin tinggi fee based berarti mengurangi ketergantungan bank dari pendapatan yang bersumber dari bunga.

\section{H3: Diversifikasi berpengaruh negatif terhadap risiko bank}

\section{METODOLOGI PENELITIAN}

Sampel dalam penelitian ini adalah 26 bank di Indonesia yang terdaftar di Bursa Efek Indonesia (BEI) dengan menggunakan data selama lima tahun yaitu dari tahun 2006 hingga 2010. Data yang dibutuhkan diperoleh dari OSIRIS Database, laporan keuangan perusahaan dan sumber sumber lain yang relevan. Variabel Dependen pengukuran risktaking sebagai variabel dependen akan menggunakan CAR(Jimenez et.al, 2007; Angkinand dan Wihlborg, 2007 dan 2011). Selain itu penulis juga akan menggunakan NPL untuk mengukur risk taking. Rumus menghitung CAR adalah sebagai berikut:

$$
C A R=\frac{\text { Modal }(\text { Modal inti }+ \text { Modal pelengkap })}{\text { Aktiva Tertimbang Menurut Risiko }(\text { ATMR })}
$$

Keterangan :

Modal Inti : Modal disetor, cadangan, laba ditahan, agio saham dll

Modal Pelengkap : Berasal dari cad. Revaluasi Aktiva Tetap (selisih penilaian kembali Aktiva Tetap dengan persetujuan dirjen pajak), Cad. Penghapusan Aktiva yang diklasifikasikan (cad. yang dibentuk dengan cara membebani lap. $\mathrm{R} / \mathrm{L}$ tahun berjalan), modal kuasi /capital instrument (warkat yang memiliki sifat seperti modal), pinjaman subordinasi (pinjaman antar bank dengan persetujuan BI dengan jangka waktu min. 5 tahun dan bila pelunasan sebelum jatuh tempo harus persetujuan $\mathrm{BI}$ ).

ATMR

Nilai total masing-masing aktiva bank setelah dikalikan dengan masing-masing bobot risiko aktiva tersebut. Risiko yang dimasukkan dalam hal ini menyangkut risiko pasar, risiko kredit dan risiko operasional. 
Non Performing Loan (NPL), yang merupakan perbandingan antara total kredit bermasalah terhadap total kredit yang diberikan adalah risiko yang dihadapi bank karena menyalurkan dananya dalam bentuk pinjaman kepada masyarakat (Masyud , 2004). Rasio ini

\section{Sedangkan Variabel Independen:}

- Konsentrasi Kepemilikan (Ownership concentration), yang merupakan ukuran sebaran kepemilikan suatu bank akan di ukur dengan menggunakan HirschmanHerfindahl Index (HHI). Metode serupa juga digunakan oleh Pham et,al (2003), Fazlzadeh et,al (2011), Céspedes (2008).

$$
H H I=\sum_{i=1}^{n} s_{i}^{2}
$$

Dimana $S_{\mathrm{i}}$ adalah proporsi kepemilikan pemilik saham dan $n$ adalah jumlah pemegang saham. Jika nilai HHI mendekati 1 hal itu menunjukkan bahwa kepemilikan semakin terkonsentrasi dirumuskan sebagai berikut (SE BI No 6/73/INTERN DPNP tgl 24 Desember 2004):

$$
N P L=\frac{\text { Total Kredit Bermasalah }}{\text { Total Kredit }}
$$

sebaliknya jika mendekati 0 menandakan kepemilikan semakin menyebar.

\section{Keterbukaan (Disclosure)}

Keterbukaan atas pelaporan informasi bank akan diukur menggunakan metodologi yang digunakan oleh Baumann dan Nier (2004), Nier (2005) dan Huang (2006). Indeks ini mengukur keterbukaan informasi dalam 6 kategori yang masing-masing kategori tersebut di turunkan lagi kedalam 17 sub kategori. Selanjutnya 17 sub kategori tersebut terbagi lagi dalam 34 item. Selengkapnya item-item tersebut dapat dilihat pada tabel berikut:

\begin{tabular}{|c|c|c|}
\hline Kategori & Sub kategori & Item \\
\hline \multirow{14}{*}{$\begin{array}{c}1 \\
\text { Loans }\end{array}$} & \multirow{4}{*}{$\begin{array}{c}\text { sk1 } \\
\text { Loans by maturity }\end{array}$} & Loans \& Advances $<3$ months \\
\hline & & Loans \& Advances 3 - 12 Months \\
\hline & & Loans and Advances 1 - 5 Years \\
\hline & & Loans \& Advances $>5$ years \\
\hline & \multirow{3}{*}{$\begin{array}{c}\text { sk2 } \\
\text { Loans by type }\end{array}$} & Residential Mortgage Loans \\
\hline & & Other Mortgage Loans \\
\hline & & Other Consumer/ Retail Loans \\
\hline & \multirow{3}{*}{$\begin{array}{c}\text { sk3 } \\
\text { Loans by counterparty }\end{array}$} & Corporate \& Commercial Loans \\
\hline & & Other Loans \\
\hline & & Loans and Advances to Banks \\
\hline & $\begin{array}{c}\text { sk4 } \\
\text { Problem loans }\end{array}$ & Impaired Loans / Gross Loans - \% \\
\hline & \multirow{3}{*}{$\begin{array}{c}\text { sk5 } \\
\text { Problem loans by type }\end{array}$} & +90 Days past due \\
\hline & & Nonaccrual Loans \\
\hline & & Restructured Loans \\
\hline \multirow{4}{*}{$\begin{array}{l}2 \\
\text { Other Earning } \\
\text { Assets }\end{array}$} & \multirow{2}{*}{$\begin{array}{c}\text { Sk6 } \\
\text { Securities by type }\end{array}$} & Other Earning Assets \\
\hline & & $\begin{array}{l}\text { Memo: Government Securities included } \\
\text { Above }\end{array}$ \\
\hline & \multirow{2}{*}{$\begin{array}{c}\text { sk7 } \\
\begin{array}{c}\text { Securities by holding } \\
\text { purpose }\end{array}\end{array}$} & Trading Securities and at FV through Income \\
\hline & & Held to Maturity Securities \\
\hline \multirow{3}{*}{$\begin{array}{c}3 \\
\text { Deposits }\end{array}$} & \multirow{3}{*}{$\begin{array}{c}\text { sk8 } \\
\text { Deposits by maturity }\end{array}$} & Retail Deposits $<3$ months \\
\hline & & Retail Deposits 3 - 12 Months \\
\hline & & Retail Deposits 1 - 5 Years \\
\hline
\end{tabular}

Tabel 1. Indeks Keterbukaan 
JURNAL MANAJEMEN VOL 4 NO.2 DESEMBER 2014

\begin{tabular}{|c|c|c|}
\hline & & Retail Deposits $>5$ Years \\
\hline & $\begin{array}{c}\text { sk9 } \\
\begin{array}{c}\text { Deposit by type of } \\
\text { customer }\end{array} \\
\end{array}$ & Deposits from Banks \\
\hline \multirow{2}{*}{$\begin{array}{c}4 \\
\text { Other Funding }\end{array}$} & $\begin{array}{c}\text { sk10 } \\
\text { Money market funding }\end{array}$ & $\begin{array}{l}\text { Total Deposits, Money Market and Short- } \\
\text { term Funding }\end{array}$ \\
\hline & $\begin{array}{c}\text { sk11 } \\
\text { Long-term funding } \\
\end{array}$ & Total Long Term Funding \\
\hline \multirow{7}{*}{$\stackrel{5}{\text { Memo Lines }}$} & $\begin{array}{c}\text { sk12 } \\
\text { Reserves }\end{array}$ & Impaired Loans (Memo) \\
\hline & \multirow{4}{*}{$\begin{array}{l}\text { sk13 } \\
\text { Capital }\end{array}$} & Regulatory Tier 1 Capital \\
\hline & & Tier 1 Ratio - \% \\
\hline & & Tier 1 Capital \\
\hline & & Total Capital \\
\hline & $\begin{array}{c}\text { sk14 } \\
\text { Contingent liabilities }\end{array}$ & Total Business Volume \\
\hline & $\begin{array}{c}\text { sk15 } \\
\text { Off-balance sheet items }\end{array}$ & Memo: Total Weighted Risks \\
\hline \multirow{2}{*}{$\begin{array}{c}6 \\
\text { Income Statement }\end{array}$} & $\begin{array}{c}\text { sk16 } \\
\text { Non-interest income } \\
\end{array}$ & Other Operating Income \\
\hline & $\begin{array}{c}\text { sk17 } \\
\text { Loan loss provisions }\end{array}$ & Loan Loss Provisions \\
\hline
\end{tabular}

Penghitungan indeks keterbukaan

Pemberian bobot poin untuk masing-masing (Discosure Index/DISC) diawali dengan dari 17 sub kategori didasarkan pada seberapa memberikan check pada setiap item keterbukaan di tabel tersebut. Jika item tersebut tersedia (dilaporkan) di laporan keuangan maka item tersebut di beri tanda check $(\sqrt{ })$, sebaliknya jika tidak tersedia maka tidak diberi tanda check. banyak item-item dari sub kategori yang bersangkutan dicantumkan (dilaporkan) dalam laporan keuangan. Adapun panduan dalam pemberian poin panduan adalah sebagai berikut:

Tabel 2. Skoring Indeks Keterbukaan

\begin{tabular}{|c|c|c|c|c|c|c|c|}
\hline \multirow{2}{*}{ Kategori } & \multirow{2}{*}{ Sub kategori } & \multirow{2}{*}{$\begin{array}{c}\text { Jumlah } \\
\text { item }\end{array}$} & \multicolumn{5}{|c|}{ Poin } \\
\hline & & & $\mathbf{0}$ & 1 & 2 & 3 & 4 \\
\hline \multirow{5}{*}{ Loans } & $\begin{array}{c}\text { sk1 } \\
\text { Loans by maturity }\end{array}$ & 4 & $0-1$ & $2-4$ & & & \\
\hline & $\begin{array}{c}\text { sk2 } \\
\text { Loans by type }\end{array}$ & 3 & 0 & $1-2$ & & & \\
\hline & $\begin{array}{c}\text { sk3 } \\
\text { Loans by counterparty }\end{array}$ & 3 & 0 & $1-3$ & & & \\
\hline & $\begin{array}{c}\text { sk4 } \\
\text { Problem loans } \\
\end{array}$ & 1 & 0 & 1 & & & \\
\hline & $\begin{array}{c}\text { sk5 } \\
\text { Problem loans by type }\end{array}$ & 3 & 0 & $1-2$ & & & \\
\hline \multirow{2}{*}{$\begin{array}{l}\text { Other } \\
\text { earning } \\
\text { assets }\end{array}$} & $\begin{array}{c}\text { Sk6 } \\
\text { Securities by type }\end{array}$ & 2 & 0 & $1-2$ & & & \\
\hline & $\begin{array}{c}\text { sk7 } \\
\begin{array}{c}\text { Securities by holding } \\
\text { purpose }\end{array} \\
\end{array}$ & 2 & 0 & 1 & 2 & & \\
\hline \multirow[t]{2}{*}{ Deposits } & $\begin{array}{c}\text { sk8 } \\
\text { Deposits by maturity }\end{array}$ & 4 & 0 & $1-4$ & & & \\
\hline & $\begin{array}{c}\text { sk9 } \\
\text { Deposit by type of } \\
\text { customer }\end{array}$ & 1 & 0 & 1 & & & \\
\hline
\end{tabular}


JURNAL MANAJEMEN VOL 4 NO.2 DESEMBER 2014

\begin{tabular}{|c|c|c|c|c|c|c|c|}
\hline \multirow{2}{*}{$\begin{array}{l}\text { Other } \\
\text { funding }\end{array}$} & $\begin{array}{c}\text { sk10 } \\
\text { Money market funding }\end{array}$ & 1 & 0 & 1 & & & \\
\hline & $\begin{array}{c}\text { sk11 } \\
\text { Long-term funding }\end{array}$ & 1 & 0 & 1 & & & \\
\hline \multirow{4}{*}{ Memo lines } & $\begin{array}{c}\text { sk12 } \\
\text { Reserves } \\
\end{array}$ & 1 & 0 & 1 & & & \\
\hline & $\begin{array}{c}\text { sk13 } \\
\text { Capital }\end{array}$ & 4 & 0 & 1 & 2 & 3 & 4 \\
\hline & $\begin{array}{c}\text { sk14 } \\
\text { Contingent liabilities } \\
\end{array}$ & 1 & 0 & 1 & & & \\
\hline & $\begin{array}{c}\text { sk15 } \\
\text { Off-balance sheet items } \\
\end{array}$ & 1 & 0 & 1 & & & \\
\hline \multirow{2}{*}{$\begin{array}{l}\text { Income } \\
\text { statement }\end{array}$} & $\begin{array}{c}\text { sk16 } \\
\text { Non-interest income }\end{array}$ & 1 & 0 & 1 & & & \\
\hline & $\begin{array}{c}\text { sk17 } \\
\text { Loan loss provisions }\end{array}$ & 1 & 0 & 1 & & & \\
\hline
\end{tabular}

Indeks keterbukaan (DISC) untuk setiap emiten kemudian di hitung dengan menggunakan rumus:

$$
D I S C=\frac{1}{21} \sum_{s=1}^{17} s_{1}
$$

Dimana, $s$ poin total dari dari suatu sub kategori yang keseluruhan berjumlah 17 sub kategori. Total poin kemudian dibagi dengan 21 dan hasilnya merupakan indek keterbukaan bagi emiten yang bersangkutan.

- Diversifikasi, akan menggunakan fee based dibagi total revenue sebagai proksi.

Adapun unsur-unsur dalam laporan keuangan yang termasuk dalam hal ini adalah pendapatan: provisi dan komisi, transaksi valuta asing, laba transaksi surat berharga pendapatan non operasional..

Adapun model penelitian yang akan diuji adalah:

$$
\begin{aligned}
& C A R_{i, t}=\alpha_{0}-\beta_{1} H_{H I}+\beta_{2} \text { DISC }_{i, t}+\beta_{3} F B_{3 i, t}+\varepsilon_{i, t} \\
& N P L_{i, t}=\alpha_{0}+\beta_{1} H H I_{i, t}-\beta_{2} \text { DISC }_{i, t}-\beta_{3} F B_{3 i, t}+\varepsilon_{i, t}
\end{aligned}
$$

Dimana risk taking yang merupakan diproksi dengan indeks keterbukaan yang variabel dependen di proksi dengan $\boldsymbol{C A} \boldsymbol{R}$ dan digunakan Baumann dan Nier (2004) dan NPL, variabel dependen konsentrasi kepemilikan diproksi dengan indeks HirschmanHerfindahl (HHI), variabel keterbukaan $(\boldsymbol{D I S C})$ diversifikasi diukur dengan proksi fee based income $(\boldsymbol{F B})$.

\section{HASIL DAN PEMBAHASAN}

Sebelum melakukan uji regresi peneliti 2003), yaitu Autokorelasi, Multikolinearitas, Normalitas dan Heteroskedastisitas dan akan melakukan uji asumsi klasik (Gujarati, hasilnya diringkas sebagai berikut:

\section{Tabel 3 Rangkuman Uji Asumsi Klasik}

\begin{tabular}{|c|c|c|c|}
\hline Normalitas & Autokorelasi & Heterokedastisitas & Multikolinearitas \\
\hline $\begin{array}{c}\text { Tidak } \\
\text { Normal }\end{array}$ & Ada & Ada & Tidak Ada \\
\hline
\end{tabular}

Sebelum pengujian hipotesis penulis terlebih dahulu merangkum data-data yang digunakan kedalam table statistik deskriptif yang menggambarkan data-data yang digunakan. 
Tabel 4 Statistik Deskriptif

\begin{tabular}{lccccc}
\hline & Min & Max & Mean & Med & SDev \\
\cline { 2 - 6 } Risk_CAR & $-0,223$ & 0,431 & 0,175 & 0,161 & 0,076 \\
Risk_NPL & 0,004 & 0,252 & 0,042 & 0,365 & 0,040 \\
Konsentrasi & 0,055 & 1,000 & 0,421 & 0,200 & 0,239 \\
Diversifikasi & 0,030 & 0,400 & 0,200 & 0,570 & 0,081 \\
Keterbukaan & 0,365 & 0,950 & 0,576 & 0,032 & 0,101 \\
\hline \multicolumn{1}{c}{$\mathbf{N}$} & & $\mathbf{1 3 0}$ & & & \\
\hline
\end{tabular}

Pada table diatas memperlihatkan tingkat risiko bank sampel yang diukur dengan CAR memiliki nilai terendah sebesar $-0,223$ atau $22,3 \%$. Nilai CAR yang sangat rendah ini tidak akan ditemui pada bank-bank yang berjalan normal. Nilai minus ini di miliki oleh Bank Mutiara yang sebelum bernama Bank Century yang merupakan hasil merger tiga bank yaitu Bank Pikko, Bank Danpac, dan Bank CIC yang memang mengalami masalah sejak tahun 2005. Sedangkan nilai tertinggi sebesar $43 \%$ dan tingkat CAR rata-rata sebesar $17,5 \%$ atau jauh diatas batas minimal yang dikategorikan sebagai bank sehat menurut BI yakni sekitar $8 \%$ dan sedikit lebih tinggi dari data rata-rata CAR perbankan Indonesia per september 2011 yakni sebesar $16 \%$. Pada pengukuran risiko yang di proksi dengan NPL menunjukkan nilai terkecil sebesar $0,4 \%$ dan tertinggi sebesar 25,2\%. Seperti halnya pada data CAR, nilai NPL tertinggi ini juga ditemui pada Bank Mutiara. Sedangkan nilai rata-ratanya NPL adalah 4,2\% atau masih dibawah rata-rata NPL nasional bank pemerintah sebesar 3,79\% dan swasta yang kurang dari 3\%. Pada variable konsentrasi indeks kemajemukan kepemilikan memiliki angka terendah pada 0,005 dan tertinggi 1 . Konsentrasi kepemilikan sebesar 1 atau 100\% dimiliki oleh satu pihak saja akan ditemukan pada bank-bank milik pemerintah atau bank yang sedang diambil alih oleh pemerintah melalui LPS seperti Bank Mutiara. Sedangkan nilai rata-rata sebesar 0,42 menunjukkan bahwa kelompok bank sampel mempunyai pemilik yang cukup tersebar merata atau tidak berada di sejumlah kecil pemilik saja dan selisih rata-rata setiap bank dengan total bank mencapai 24\% (standar deviasi). Variable diversifikasi yang mengukur besaran pendapatan bank diluar operasi utama memiliki angka tertinggi sebesar $40 \%$ dan terendah 3\% dengan rata-rata sebesar $20 \%$ serta standar deviasi sebesar 8\%. Angka rata-rata hingga 20\% ini menunjukkan fee based telah menjadi sumber pemasukan non operasional yang menguntungkan bagi bankbank di Indonesia. Variable terakhir adalah keterbukaan yang secara rata-rata indeks pengungkapan informasi bank-bank sampel ada di tingkatan yang cukup (indeks 0,57). Di mana indeks pengungkapan terendah sebesar 0,36 dan tertinggi 0,95 . Selanjutnya, pengujian setiap hipotesis di rangkum dalam table 4.7.

Tabel 5 Pengujian Statistik Hipotesis

\begin{tabular}{|c|c|c|c|c|c|c|}
\hline \multirow{3}{*}{$\begin{array}{c}\text { Variabel } \\
\text { Independen }\end{array}$} & \multicolumn{6}{|c|}{ Variabel Dependen } \\
\hline & \multicolumn{3}{|c|}{ CAR } & \multicolumn{3}{|c|}{ NPL } \\
\hline & Koefisien & t-value & Sig & Koefisien & t-value & Sig \\
\hline Konstanta & \multicolumn{3}{|c|}{0,148} & \multicolumn{3}{|c|}{0,084} \\
\hline Konsentrasi (H:1) & $-0,036$ & $-1,309$ & 0,193 & 0,014 & 0,965 & 0,336 \\
\hline Keterbukaan (H:2) & 0,157 & 2,407 & $0,018 * *$ & $-0,111$ & $-3,190$ & $0,002 * * *$ \\
\hline Diversifikasi (H:3) & 0,236 & 2,954 & $0,004 * * *$ & $-0,085$ & $-2,003$ & $0,047 * *$ \\
\hline R Square & \multicolumn{3}{|c|}{0,098} & \multicolumn{3}{|c|}{0,094} \\
\hline
\end{tabular}

Hipotesis pertama menyatakan bahwa tingkat konsentrasi kepemilikan berdampak positif pada tingkat risiko, yakni semakin tinggi konsentrasi kepemilikan maka semakin tinggi pula risiko suatu bank. Pengukuran risiko yang pertama menggunakan angka rasio kecukupan modal atau CAR yang berarti semakin tinggi angkanya maka semakin rendah risikonya dan sebaliknya (bertanda negatif). Sedangkan ukuran kredit bermasalah atau NPL 
mensyaratkan semakin tinggi angka NPL semakin tinggi pula risikonya (bertanda positif). Dari table hasil pengujian didapatkan tanda koefisien yang telah sesuai atau searah dengan pernyataan dalam hipotesis pertama, akan tetapi nilai uji statistiknya tidak signifikan. Dari hasil ini kemudian dapat disimpulkan bahwa tingkat konsentrasi kepemilikan tidak mempengaruhi tingkat risiko suatu bank. Temuan ini berkebalikan dari hasil beberapa penelitian terdahulu yang diungkap pada bab sebelumnya. Marcus (1984) berpendapat tidak selamanya pemilik (yang terkonsentrasi) berkeinginan untuk mengambil risiko tinggi demi mengejar insentif yang tinggi pula karena mereka juga berkepentingan untuk menjaga investasi mereka di perusahaan tersebut. Di samping itu juga tidak dapat dipungkiri bahwa setiap pemilik pada dasarnya memiliki preferensi risiko berbeda. Pendapat serupa juga dikemukakan oleh Deng dan Elyasiani (2008). Dari sampel bank yang digunakan juga terlihat ada beberapa bank-bank besar yang kepemilikannya terkonsentrasi tapi ternyata memiliki kinerja yang baik dengan tingkat CAR tinggi dan NPL yang rendah (contohnya, Bank Mandiri, Permata atau Bank BCA). Angkinand dan Wihlborg (2007) menyatakan bahwa hubungan antara tingkat konsentrasi kepemilikan dengan risiko juga tergantung dengan kondisi kebijakan tingkat penjaminan simpanan yang berlaku di Negara bersangkutan. Untuk kasus di Indonesia, sebelum dinaikkan menjadi Rp 2 miliar pada akhir 2008, batas simpanan yang dijamin adalah Rp 100 juta. Jika pemerintah melakukan penjaminan pada tingkat simpanan yang tinggi, maka hal itu dapat mengurangi sikap kehatihatian pemilik atau manajemen dalam menjalankan operasi perusahaan. Menurut Taswan (2011), dalam desertasinya, menyebutkan faktor kepatuhan terhadap regulasi juga berpengaruh terhadap risiko atau dengan kata lain, hubungan antara variable kepemilikan dan risiko juga bisa semakin menguat jika unsur kebijakan pemerintah juga dilibatkan. Penelitian ini belum memasukkan variable-variabel lain seperti yang telah dijelaskan tersebut dan jumlah sampel yang cukup sedikit jika dibandingkan total bank dalam industri serta belum mempertimbangkan jenis kepemilikan (institusional, manajerial, pemerintah, asing) seperti yang diungkapkan oleh Barth et,al (2000) yang berpendapat bahwa kepemilikan saja mungkin tidak selalu dapat mempengaruhi langsung terhadap kinerja perbankan, namun harus dibedakan berdasarkan jenisnya atau justru menggunakannya sebagai variable moderasi. Hasil penelitian Nuringsih (2010), maupun Ismiyanti dan Mamduh (2003) menyimpulkan bahwa kepemilikan manajerial berdampak signifikan terhadap tingkat risiko karena pengelola perusahaan yang juga memiliki saham di perusahaan akan menyelaraskan kebijakan perusahaan dengan kepentingannya. Taswan (2011), menyimpulkan kepemilikan swasta domestik dan kepemilikan asing berpengaruh positif terhadap tingkat risiko. Pemegang saham bank swasta, baik domestik maupun asing telah melakukan moral hazard daripada mereduksi risiko perbankan. Hal ini didukung oleh pengaruh charter value ${ }^{2}$ terhadap risiko perbankan. Semakin rendah charter value, semakin tinggi risikonya. Charter value ini menjadi insentif dalam memperkuat hubungan kepemilikan bank dengan tingkat risiko. Ketiadaan pertimbangan variablevariabel diatas mungkin menjadi salah satu alasan yang menyebabkan hasil pengujian pada penelitian ini tidak sesuai dengan harapan.

Hipotesis kedua penelitian ini menduga tingkat pengungkapan informasi suatu bank akan berdampak negatif terhadap tingkat risiko bank. Semakin tinggi informasi yang diungkap ke publik oleh bank maka semakin kecil risikonya dan begitu juga sebaliknya, jika informasi yang diungkap rendah maka risiko bank tinggi. Pengujian statistik menunjukkan hasil signifikan pada kedua variable pengukur risiko. Hasil ini sejalan dengan kesimpulan penelitian oleh Bauman dan Nier (2004), Laeven dan Levine (2006), Hirtle (2007), Taswan (2011) maupun Cordella dan Yeyati (1998). Pada variable CAR koefisien memiliki tanda positif yang berarti semakin tinggi pengungkapan informasi maka semakin tinggi

\footnotetext{
${ }^{2}$ Nilai sekarang dari ekspektasi laba bank di masa depan yang diperoleh dari kemampuan mengakses pasar, reputasi dan kepemilikan informasi pasar yang memadai. Dihitung sebagai selisih antara market value dengan book value perusahaan (Guttentag and Herring, 1983)
} 
pula rasio kecukupan modal, CAR bank atau diartikan semakin rendahnya risiko bank. Sedangkan pada variable NPL menghasilkan koefisien bertanda negatif yang berarti semakin tinggi pengungkapan informasi maka semakin rendah pula NPL atau tingkat risiko bank. Seperti yang diungkapkan oleh Taswan (2011) bahwa kepatuhan terhadap regulasi, yang salah satunya adalah kepatuhan dalam mengungkap informasi yang dibutuhkan oleh publik, akan berdampak baik terhadap risiko bank. Semakin tinggi kepatuhan regulasi, semakin rendah tingkat risiko perbankan. Flannery (2001), Bliss dan Flannery (2002) menyatakan bahwa regulator bank menggunakan pendisiplinan pasar sebagai alat pengawasan dan kontrol risiko bank. Jika publik dan deposan dapat mengakses dan menilai tingkat risiko bank melalui informasi yang diungkap maka risiko atas kebijakan yang akan diambil pengelola bank akan menjadi lebih efisien karena mereka menyadari semakin tinggi risiko yang mereka ambil maka semakin tinggi pula tingkat kembalian yang diminta oleh investor/publik. Kasus di Indonesia adalah fraud yang dilakukan oleh Bank Century yang pada tahun 2005 mengalami kekurangan likuiditas parah yang menyebabkan tidak dapat mengikuti proses kliring yang ternyata pada tahun 2003 .

Hipotesis ketiga atau yang terakhir menyatakan bahwa tingkat risiko akan dipengaruhi oleh diversifikasi pendapatan secara negatif atau semakin tinggi diversifikasi pendapatan maka semakin rendah risiko suatu bank dan sebaliknya. Pengujian hipotesis ini menunjukkan dukungan terhadap hipotesis yakni signifikan secara statistik. Koefisien menunjukkan tanda positif pada variable rasio kecukupan modal (CAR) dan negatif pada kinerja kredit bermasalah. Diversifikasi terbukti mampu mengurangi risiko bank. Semakin tinggi fee based menunjukkan bank tidak lagi semata bergantung pada pendapatan dari sector perkreditan sehingga mampu mempertahankan tingkat pendapatan yang memadai untuk membiayai seluruh operasional bank untuk memperoleh keuntungan bisnis serta tetap menjaga rasio kecukupan modalnya dengan baik. Hasil ini mendukung penelitian oleh Smith et.al, (2003) dan Tacneng (2009) yang menyimpulkan bahwa fee based mampu menurunkan risiko dari suatu bank karena semakin tinggi fee based. Hasil ini berkebalikan dengan temuan penelitian Odesanmi and Wolfe (2007) yang menemukan hubungan positif antara diversifikasi dan risiko. Mereka menjelaskan hasil itu dalam 3 hal: pertama, meningkatnya aktifitas diluar operasi tradisional perbankan menyebabkan turunnya kualitas pengawasan pada kredit yang disalurkan, kedua aktifitas diluar operasi tradisional bank akan semakin meningkatkan risiko dan ketiga tingginya diversifikasi akan semakin meningkatkan volatilitas pendapatan. Dengan adanya fee based pengawasan bank pada dana kredit akan sedikit terabaikan karena pendapatan dari fee based akan menutupi kerugian dari kredit macet tersebut.

\section{PENUTUP \\ Simpulan}

Penelitian ini memberikan hasil yang konsisten dengan penelitian-penelitian sebelumnya yang menemukan bahwa risiko suatu bank dapat dipengaruhi oleh tingkat pengungkapan informasi dan tingkat diversifikasi sumber pendapatan. Semakin tinggi indeks pengungkapan informasi dan diversifikasi maka semakin rendah risiko. Variable kepemilikan telah menunjukkan arah yang sesuai terhadap risiko tapi pengaruhnya tidak nyata secara statistik. Meskipun demikian hasil penelitian belum dapat digunakan sebagai acuan untuk menggeneralisir fenomena serupa dalam industri perbankan di Indonesia.

\section{Keterbatasan dan Saran}

Jumlah sampel yang hanya sejumlah 26 bank belum mewakili industri perbankan Indonesia. Variable kepemilikan bank belum mempertimbangkan detil-detil tertentu yang digunakan dalam beberapa penelitian sebelumnya, seperti jenis kepemilikan: manajerial, institusional, swasta dalam maupun asing dan pemerintah yang diidentifikasi memiliki perbedaan karakter dalam pengelolaan bank maupun preferensi risiko. Untuk itu pada penelitian selanjutnya, sebaiknya kekurangan tersebut dapat di perbaiki termasuk dalam penggunaan metodologi dan penggunaan proksi-proksi pengukuran variable yang lain. 


\section{DAFTAR PUSTAKA}

Albert J. Boro, Jr., 1986, "Banking Disclosure Regimes for Regulating Speculative Behavior". California Law Review, Vol. 74, No. 2

Angkinand, Apanard and Clas Wihlborg., 2007, "Deposit Insurance Coverage, Ownership, and Banks' Risk-taking in Emerging markets”, Journal of International Money and Finance

Angkinand, Apanard and Clas Wihlborg., 2011, "Implicit Guarantees, Governance and Banks' Risk-Taking in European Banks through the Crisis“", University of Illinois, Springfield

Barth, James R., Gerard Caprio, Jr., and Ross Levine, 2000, "Banking System Around the Globe : Do Regulation and Ownership Affect Performance and Stability?", The World Bank Series Paper.

Bathala, C.T., Moon, K.P., dan Rao, R.P., 1994, "Managerial Ownership, Debt Policy and the Impact of Institutional Holdings: An Agency Perspective“. Journal of Financial Management

Baumann, U., dan Nier, E., 2004. "Disclosure, Volatility, and Transparency: An Empirical Investigation Into the Value of Bank Disclosure“. FRBNY Economic Policy Review

Bliss, Robert, and Mark J. Flannery, 2002, "Market Discipline In The Governance Of U.S. Bank Holding Companies: Monitoring Vs. Influence". European Finance Review 6

Brous, P.A., dan Kini, O.1994, "The Valuation Effects of Equaty Issues and the Level of Institutional Ownership: Evidence From Analysis' Earning Forecast“. Journal of Financial Management

Cebenoyan, A. Sinan, Elizabeth S. Cooperman dan Charles A., 1999, "Ownership Structure, Charter Value, and Risk-Taking Behavior for Thrifts". Financial Management

Céspedes, Jacelly., Maximiliano González and Carlos A. Molina., 2008, "Ownership Concentration and the Determinants of Capital Structure in Latin America“, FMA Annual Meeting Papers
Chun, Sun Eae, Nagano, Mamoru and Lee Min Hwan., 2010, "Ownership Structure and Risk-taking Behavior: Evidence from Banks in Korea and Japan“, Munich Personal RePEc.

Ciancanelli, P., and J.A.R. Gonzalez., 2000, "Corporate Governance in Banking: A Conceptual Framework", Social Science Research Network, Electronic Paper Collection

Cordella, Tito, and Eduardo Levy Yeyati, 1998. "Public Disclosure and Bank Failures", Intenational Monetery Fund Paper Series

Demsetz, Harold dan Kenneth Lehn., 1985, "The Structure of Corporate Ownership: Causes and Consequences," Journal of Political Economy, University of Chicago Press, vol. 93

Dendawijaya, Lukman. (2005). “Manajemen Perbankan". Edisi Kedua: Ghalia Indonesia. Bogor

Deng, Saiying dan Elyas Elyasiani., 2008, "Institutional Ownership Stability and BHC Performance", Journal of Banking and Finance Volume 32, Issue 9

Fazlzadeh, Alireza, Ali Tahbaz and Hendi Kazem Mahboubi., 2011, "The Examination of the Effect of Ownership Structure on Firm Performance in Listed Firms of Tehran Stock Exchange Based on the Type of the Industry". International Journal of Business and Management

Flannery, Mark J. 2001. "The Faces of 'Market Discipline". Journal of Financial Services Research.

Flannery, Mark J., Simon H. Kwan, and M. Nimalendran. 2004. "Market Evidence on the Opaqueness of Banking Firms Assets", Journal of Financial Economics.

Fuady, Munir, 1993., "Proteksi Terhadap Pemegang Saham Minoritas di Dalam Perusahaan Publik", Dalam Newsletter, No.L4/IV/September

Ghozali, Imam,. Aplikasi Analisis Multivariate dengan Program SPSS, Badan Penerbit Universitas Diponegoro Semarang, Tahun 2007 
Gujarati, Damodar. 2003. 'Basic Econometrics'. Fourth Edition. The McGraw-Hill Companies

Gunarsih, Tri., 2003, Struktur Kepemilikan Sebagai Salah Satu Mekanisme Corporate Governance, KOMPAK, No. 08 Mei Agustus 2003.

Guttentag J., dan Herring, R., "The insolvency of financial institutions: Assessment and regulatory disposition", In Crises in the economic and financial structure, edited by Paul Wachtel, Lexington: Lexington Books Himmelberg, C.P., R.G. Hubbard dan D. Palia, 1999. "Understanding The Determinants Of Managerial Ownership And The Link Between Ownership And Performance". Journal Financial Economic.

Hirtle, Beverly., 2007, Public Disclosure, Risk, and Performance at Bank Holding Companies. Federal Reserve Bank of New York

Holderness, Clifford G., Randall S. Kroszner, and Dennis P. Sheehan. "Were the Good Old Days That Good? Changes in Managerial Stock Ownership Since the Great Depression." Journal of Finance 54 (1999)

Huang, Rocco., 2006, "Bank Disclosure Index Global Assessment of Bank Disclosure Practices", World Bank Paper Series

Ismiyanti, Fitri dan Mamduh M. Hanafi,. 2003. "Kepemilikan Manajerial, Kepemilikan Institusional, Risiko, Kebijakan Hutang dan Kebijakan Dividend: Analisis Persamaan Simultan". Simposium Nasional akuntansi VI.

Itturiaga, Felix J., dan J. Lopez Sanz. 2000. Ownership Structure, Corporate Value and Firm Investment: a Spanish Firms Simultaneous Equation Analysis. Direction General de Ensenanza Superior e Investigacion Cientifica.

Jiménez, Gabriel, Jose A. Lopez and Jesús Saurina, 2007, "How Does Competition Impact Bank Risk-Taking?", Federal Reserve Bank of San Francisco Working Paper Series

Kasmir. 2008. Bank dan Lembaga Keuangan Lainnya. Edisi Revisi Jakarta: PT. Raja Grafindo
Kim, Kenneth A., Sang-Hyop Lee, dan S. Ghon Rhee, 2007., "Large shareholder Monitoring and Regulation: The Japanese Banking Experience", Journal of Economics and Business

Kuncoro, Mudrajad \& Suhardjo, 2002, Manajemen Perbankan Teori Dan Aplikasi, BPFE, Yogyakarta

La Porta, Rafael, Florencio Lopez-de-Silanes, Andrei Shleifer, 1998, Corporate Ownership Around The World

Laeven, Luc, dan Ross Levine, 2006, Complex Ownership Structures and Corporate Valuations, National Bureau of Economic Research

Marcus, A.J., 1984, "Deregulation and Bank Financial Policy," Journal of Banking and Finance

Masyhud, Ali., 2004, Asset Liability Management: Manyiasati Risiko Pasar dan Risiko Operasional, PT. Gramedia Jakarta

Machfoedz, Mas'ud \& Payamta, 1999, "Evaluasi Kinerja Perusahaan perbankan sebelum dan sesudah menjadi Perusahaan Publik di Bursa Efek Jakarta (BEJ)", Jurnal Kelola No.20/VIII/1999

Mehran, H., 1992, "Executive Insentive Plans, Corporate Control and capital Structure," Journal of Finance and Quantitative Analysis 27: 539-560.

Nier, Erlend W., 2005, "Bank Stability and Transparency", Journal of Financial Stability

Nuringsih, Kartika., 2010, "Pengaruh Profitabilitas, Kebijakan Hutang dan Kepemilikaninstitusional terhadap Kepemilikan Manajerial dan Terhadap Risiko", Jurnal Bisnis dan Akuntansi

Odesanmi, S., and Wolfe, S. (2007). "Revenue Diversification and Insolvency Risk: Evidence from Banks in Emerging Economies", Asia Pacific Journal Management

Paligorova, Teodora., 2009 "Corporate RiskTaking and Ownership Structure", Bank of Canada Working Papers series

Peter K. Pham, Petko S. Kalev, Adam B. Steen., 2003, "Underpricing, Stock Allocation, Ownership Structure and Post-Listing 
Liquidity of Newly Listed Firms", Journal of Banking \& Finance

Sandria, Arinita., 2000, Pelaksanaan Prinsip Keterbukaan oleh Emtien Dalam Pasar Modal di Indonesia, Program Magister Ilmu Hukum, Kajian Hukum Ekonomi Dan Teknologi Universitas Diponegoro Semarang.

Shleifer, Andrei, and Robert W. Vishny, 1986, "Large Shareholders and Corporate Control", The Journal Of Political Economy

Siamat, Dahlan, 2005, Manajemen Lembaga Keuangan, Edisi Keempat, Badan Penerbit Fakultas Ekonomi Universitas Indonesia, Jakarta.

Sinungan, Muchdarsayah, 1994, Strategi Manajemen Bank, Penerbit Rineka Cipta, Jakarta

Smith, Rosie, Christos Staikouras and Geoffrey Wood., 2003, Non-interest Income and Total Income Stability Publications Group, Bank of England

Solomon, A., Solomon, J. F. and M. Suto, 2004, Can the UK Experience Provide Lessons for the Evolution of SRI in Japan?, Corporate Governance: An International Review. International Conference on Corporate Governance and Board Leadership at Henley Management College UK

Susilo, Sri Y., 2000, Bank dan Lembaga Keuangan lainnya, Salemba Empat, Jakarta

Tacneng, Ruth C., 2009, Bank Diversification and Risk: Does Foreign Presence Matter? Universite de Limoges, Limoges, France

Taswan, 2011, "Kepemilikan Bank, Kepatuhan Regulasi, dan Disiplin Pasar", Desertasi Fakultas Ekonomika dan Bisnis UGM, Yogyakarta

Weston, J. Fred., Copeland, Thomas E., 1995. Manajemen Keuangan, Edisi kesembilan, Jilid I \& II, Edisi Revisi, Penerbit Binarupa Aksara, Jakarta.

Wright, P., Ferrris, S., and Awasthi, V. (1996). "Impact of Corporate Insider, Blockholder, and Institutional Equity Ownership on Firm Risk-Taking". Academy of Management Journal. 
JURNAL MANAJEMEN VOL 4 NO.2 DESEMBER 2014 